\title{
A Case Report on the Differential Diagnosis of Internal Carotid Artery Agenesis or Occlusion
}

\author{
A Case Report on the Differential Diagnosis of Internal Carotid Artery
} Agenesis or Occlusion

\author{
Bektaş Korkmaz, Gülçin Benbir Şenel, Birsen İnce \\ İstanbul University Cerrahpaşa Faculty of Medicine, Department of Neurology, İstanbul, Turkey
}

\section{Summary}

Congenital internal carotid artery (ICA) agenesis is a rare abnormality. People with this abnormality usually have adequate collateral circulation and remain asymptomatic for many years. However, patients may also present with pulsatile tinnitus, headache or blurred vision, or rarely with ischemic stroke or subarachnoid hemorrhage. Diagnosis is usually incidental with the performance of carotid artery Doppler ultrasonography or cervical/cranial magnetic resonance imaging owing to other symptoms. ICA agenesis might also be misdiagnosed as ICA occlusion. In this manuscript, we report a patient with ICA agenesis who initially presented with facial paresthesis and was referred to our center for interventional therapy for left-sided ICA occlusion.

Keywords: Internal carotid artery, agenesis, occlusion

$\ddot{O} \mathbf{z}$

Konjenital internal karotis arteri (ICA, internal carotid artery) agenezisi nadir görülen bir anomalidir. Bu anomaliye sahip hastaların çoğu, yeterli kollateral dolaşım sayesinde uzun zaman asemptomatik olarak kalır. Az sıklıkta hastalar pulsatil tinnitus, baş ağrısı veya bulanık görme gibi yakınmalar ve nadiren iskemik inme ya da subaraknoid kanama tablosu ile başvurabilirler. Tanı genellikle başka bir nedenle yapılmış olan karotis arteri renkli Doppler ultrasonografisi veya servikal/ kranyal manyetik rezonans görüntülemeleri sırasında tesadüfen konur. Ancak dikkatli olunmadığı takdirde ICA tıkanması olarak yanlış bir tanı konulabilir. Bu yazıda, yüzünde yanma şikayeti ile başvuran ve sol ICA tıkanıklığı tanısı ile girişimsel tedavi amacıyla merkezimize yönlendirilen ancak ICA agenezi tanısı konulan bir hasta sunulmaktadir.

Anahtar kelimeler: İnternal karotis arteri, agenezi, tıkanma

\section{Introduction}

Agenesis of the internal carotid artery (ICA) was first defined following post-mortem examinations performed in 1787 (1). This is a rare congenital abnormality, with an incidence rate of $0.01 \%$ $(2,3,4)$. A recent study analyzed magnetic resonance imaging (MRI) and cerebral digital subtraction angiography (DSA) series and reported higher rates of ICA agenesis or hypoplasia at $0.13 \%$ (5). Studies have reported that ICA agenesis is more often seen on the left, and the left/right ratio of the pathology is 3:1 (6). ICA agenesis has been suggested to be a developmental variation, although its exact cause is unknown (7). The objective of this study was to report a patient with ICA agenesis who had initially presented with facial burning sensation, was diagnosed with left ICA occlusion, and referred to our center for further investigation and interventional treatment, and to discuss the differential diagnosis of internal carotid artery agenesis and occlusion.

\section{Case Report}

A man aged 58 years presented to a regional state hospital 1.5 months before with a burning sensation over his entire face and partially over the scalp, which was more prominent on the right side. Following examinations, the patient had been diagnosed as having occlusion of the right ICA; treatment with acetyl salicylic acid (100 mg) was started, and he was referred to our clinic for 
further neurointerventional evaluation and possible treatment. Detailed anamnesis revealed that patient's symptoms had started subacutely over 1-2 days, and despite intermittent fluctuations in severity, it had continued at the same severity for the last 1.5 months. He had no other neurologic symptoms. The patient had also had Type 2 diabetes for 10 years with normal blood glucose levels under oral anti-diabetic treatment. His family medical history was insignificant.

The neurologic examination was entirely normal. The National Institute of Health (NIH) stroke score was calculated as 0 points and the modified Rankin score (mRS) was 1 point. Vital signs proved to be within normal ranges. No pathologic results were obtained in routine biochemical examinations. Cranial MRI was interpreted as normal. In cranial MRangiography, the left main carotid artery, the common carotid artery (CCA), was not filling, starting from the origin of the aortic arch (Figure 1). The Left CCA was hypoplasic, and the left ICA and A1 segment of the anterior cerebral artery (ACA) was aplasic in cranial computed tomography (CT) angiography. The left middle cerebral artery (MCA) was supplied by the posterior communicating artery (PCoA), and centrally located dilatations were seen in the PCoA and anterior communicating artery (ACoA). Examination of the bone cross-sections in CT angiography revealed that the carotid canal was missing at the skull base (Figure 2A, 2B). The patient was diagnosed as having left ICA aplasia upon confirmation of these vascular abnormalities in DSA.

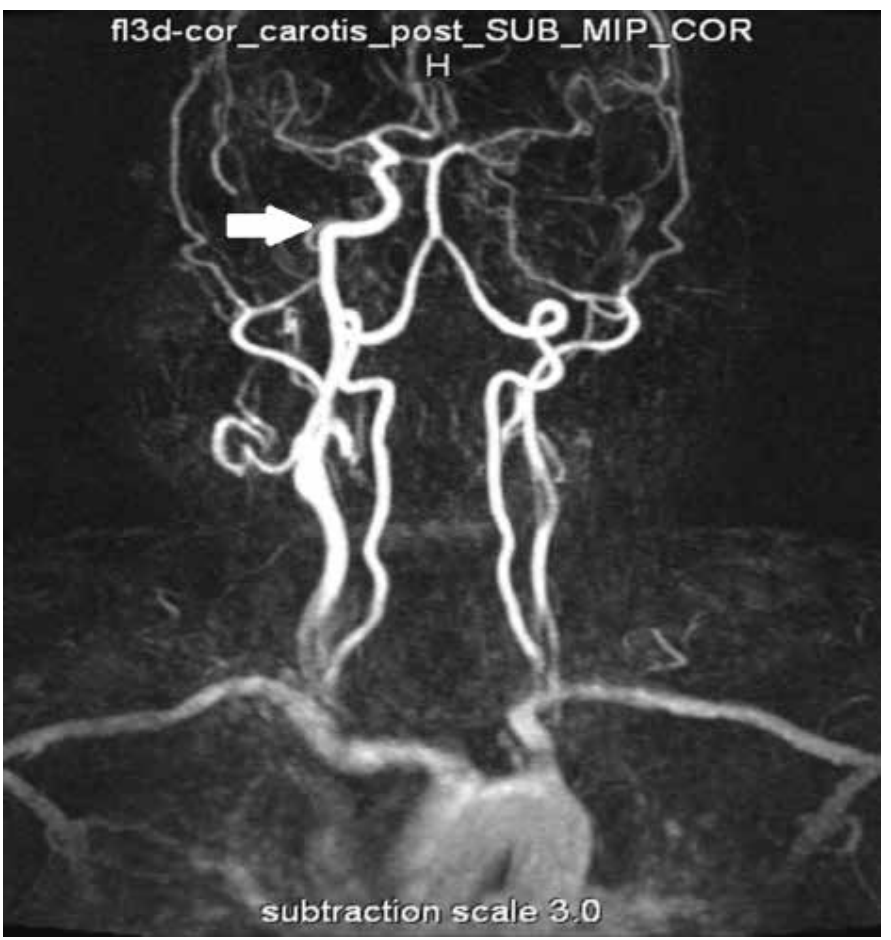

Figure 1. The patient's left common carotid artery cannot be seen after the origin of aortic arch in cranial magnetic resonance imagingangiography (white arrow indicates the right internal carotid artery, a branch of right common carotid artery)

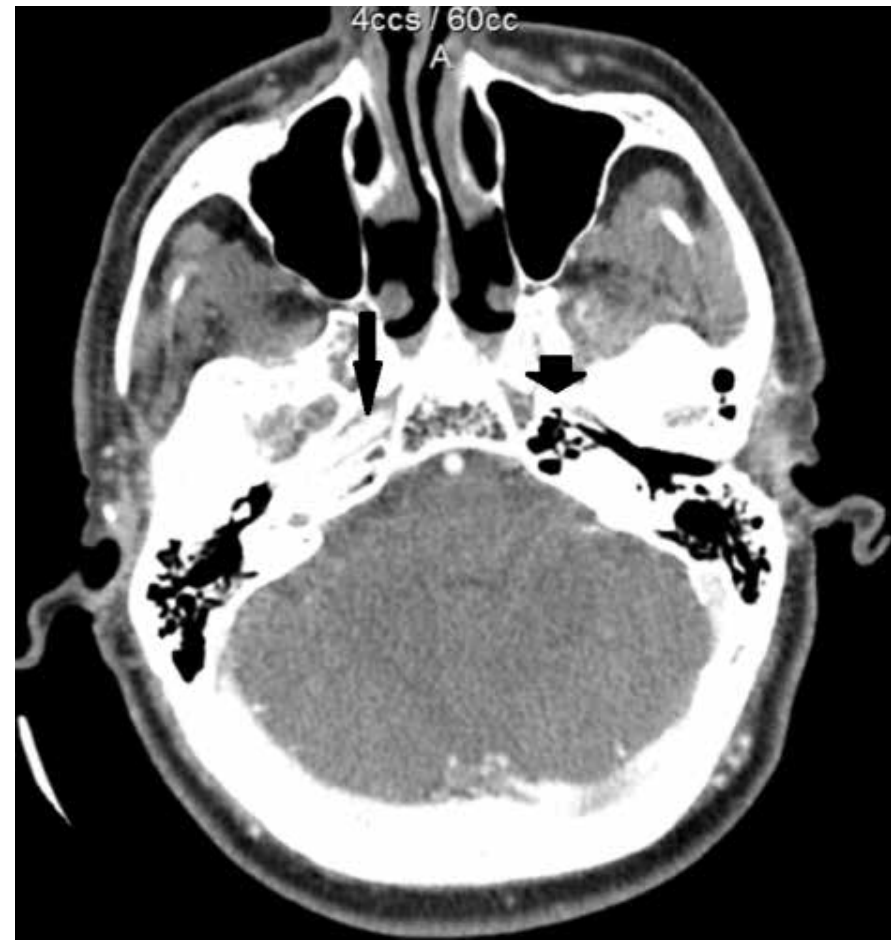

Figure 2A. The carotid canal is absent on the skull base in bone crosssections of computed tomography-angiography (the long thin arrow indicates the right carotid canal, the short thick arrow indicates the undeveloped left carotid artery)

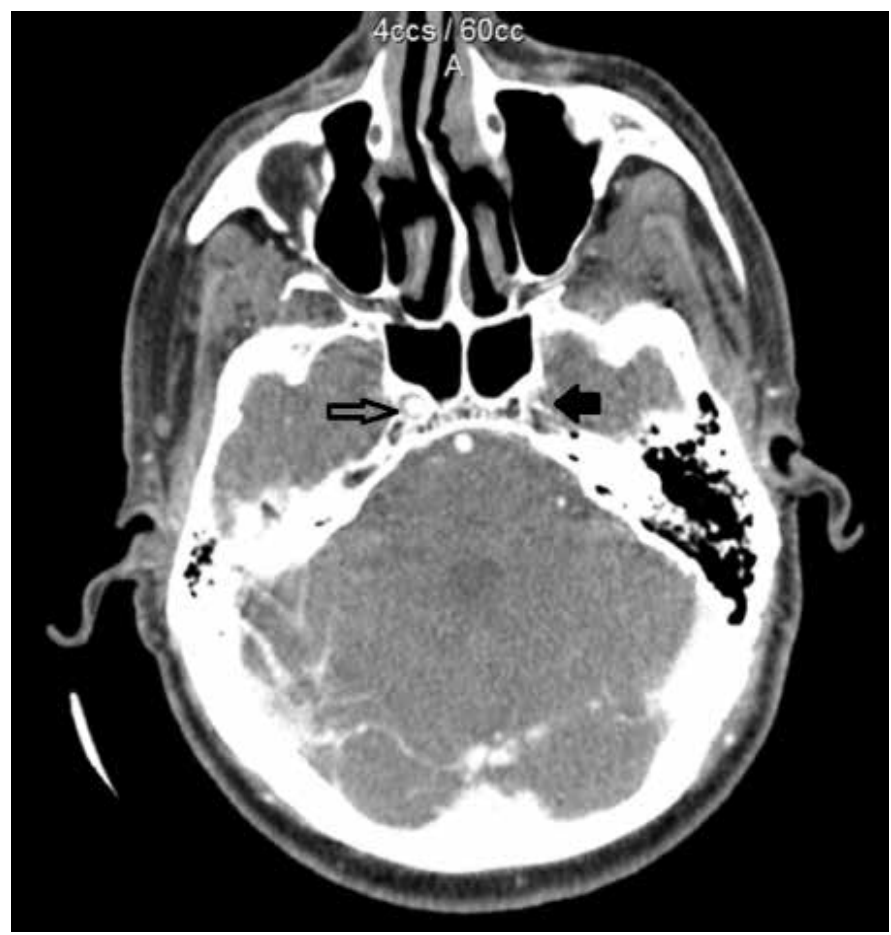

Figure 2B. The right internal carotid artery (arrow with no fill) seen at the level of cavernous sinus in computed tomography-angiography, and the internal carotid artery is absent on the left (arrow with black fill) 


\section{Discussion}

Two theories have been suggested to explain the embryogenic development of the carotid artery. According to one of these, the proximal part of the CCA and ICA develops from the $3^{\text {rd }}$ aortic arch; the other theory claims that the proximal part of the the ICA develops from the $3^{\text {rd }}$ aortic arch and CCA develops from the aortic sac (8). The carotid canal does not develop unless the ICA develops in the $3^{\text {rd }} 5^{\text {th }}$ embryonic gestational weeks (9). As in the presented case, the absence or hypoplasia of carotid canal in the bony structure of the skull base is diagnostic for ICA agenesis or hypoplasia, and differentiates this abnormality from acquired ICA obstruction or stenosis $(2,5)$.

Three types of collateral circulations have been defined in cases of ICA agenesis (10). The most common type is the fetal type, in which the ACoA supplies the ACA and PCoA supplies MCA. In the adult type, which is the second most common type, the ACoA supplies both the ACA and MCA. Finally, in the least common type, blood supply to the brain comes from the external carotid artery, contralateral ICA, and primitive vessels via transcranial anastomoses $(1,11)$. Fetal-type collateral circulation was also seen in our patient..

Collateral circulations allow most patients with ICA agenesis to remain asymptomatic. Rarely, patients might present with symptoms of pulsatile tinnitus, headache or blurred vision $(6,12)$. One patient with left ICA aplasia and sensory contralateral hemifacial paresis has also been reported (7). Our patient also presented with contralateral hemifacial burning sensation, but his neurologic examination was normal. Although the cause and effect relation between this symptom and ICA agenesis is controversial, abnormalities of the collateral circulation or other underlying concomitant developmental vascular abnormalities have been suggested. Accordingly, ruptures of aneurysms accompanying ICA agenesis have been suspected in cases of ICA agenesis, which rarely presents with ischemic stroke or subarachnoid hemorrhage (13). Intracranial aneurysms have been reported in $25-43 \%$ of patients with ICA agenesis, which is a rate much higher than the incidence of intracranial aneurysms (2-4\%) in the general population $(14,15)$. Hemodynamic impairments or developmental disorders simultaneously occurring in embryonic life have been suggested to underlie the common co-occurrence of aneurysms and ICA agenesis (15). Dilatations in PCoA and ACoA were seen in DSA in the case reported herein; however, no aneurysms were determined. The high co-occurrence rate warrants a search for aneurysms in patients with ICA agenesis and follow-up for aneurysm development, particularly in the presence of significant hemodynamic impairment.

Consequently, the differential diagnosis of ICA agenesis or hypoplasiafrom ICA obstruction is clinically important. Therefore, the absence of carotid canal among bony structures should be demonstrated in CT. Also, the common co-occurrence of congenital ICA agenesis and other vascular abnormalities, including intracranial aneurysms, should be noted in order to appropriately refer these patients for further investigation and necessary precautions.

Informed Consent: Consent form was filled out by all participants. Concept: Gülçin Benbir Şenel, Birsen İnce, Design: Gülçin Benbir Şenel, Birsen İnce, Data Collection or Processing: Gülçin Benbir Şenel, Analysis or Interpretation: Gülçin Benbir Şenel, Birsen İnce, Literature Search: Bektaş Korkmaz, Gülçin Benbir Şenel, Writer: Bektaş Korkmaz, Gülçin Benbir Şenel, Peer-review: Externally peer-reviewed. Conflict of Interest: No conflict of interest was declared by the authors. Financial Disclosure: The authors declared that this study has received no financial support.

\section{References}

1. Lie TA. Congenital Anomalies of the Carotid Arteries. Amsterdam: Excerpta Medica Foundation 1968:30-51.

2. Makowicz G, Poniatowska R, Lusawa M. Variants of cerebral arteries -anterior circulation. Pol J Radiol 2013;78:42-47.

3. Smith KR, Nelson JS, Dooley JM Jr. Bilateral 'hypoplasia' of the internal carotid arteries. Neurology 1968;18:1149-1156.

4. Afifi AK, Godersky JC, Menezes A, Smoker WB, Bell WE, Jacoby CG. Cerebral hemiatrophy, hypoplasia of internal carotid artery and intracranial aneurysm. A rare association occurring in an infant. Arch Neurol 1987;44:232-235.

5. Paşaoğlu L, Vural M, Ziraman I, Uyanık SA. Left internal carotid artery agenesis associated wiht basilar and left vertebral artery aneurysm. J Clin Imaging Sci 2011;1:60.

6. Taşar M, Yetişer S, Taşar A, Uğurel S, Gönül E, Sağlam M. Congenital absence or hypoplasia of the carotid artery: radioclinical issues. Am J Otolaryngol 2004;25:339-349.

7. Florio F, Balzano S, Nardella M, Strizzi V, Cammisa M, Bozzini V, Catapano G, D'Angelo V. Congenital absence of the internal carotid artery. Cardiovasc Intervent Radiol 1999;22:74-78.

8. Sliwka U, Schmidt P, Reul J, Noth J. Agenesis of the internal carotid artery: color Doppler, CT, and MR angiography findings. J Clin Ultrasound 1998;26:213216.

9. Hills J, Sament S. Bilateral agenesis of the internal carotid artery associated with cardiac and other anomalies: case report. Neurology 1968;18:142-146.

10. Farhat W, Ahdab R, Hosseini H. Congenital agenesis of internal carotid artery with ipsilateral Horner presenting as focal neurological symptoms. Vasc Health Risk Manag 2011;7:37-40.

11. Midkiff RB, Boykin MW, McFarland DR, Bauman JA. Agenesis of the internal carotid artery with intercavernous anastomosis. AJNR Am J Neuroradiol 1995; 16:1356-1359.

12. Cohen JE, Gomori JM, Leker RR. Internal carotid artery agenesis: diagnosis, clinical spectrum, associated conditions and its importance in the era of stroke interventions. Neurol Res 2010;32:1027-1032.

13. Sun J, Jiang D, Zhang S. Bilateral internal carotid artery agenesis with artery compression of the brain parenchyma. J Neurol Sci 2008;272:191-193.

14. Kunishio K, Yamamato Y, Susami N, Asari S. Agenesis of the left internal carotid artery, common carotid artery, and main trunk of the external carotid artery associated with multiple cerebral aneurysyms. Surg Neurol 1987;27:177181.

15. Lee JH, Oh CW, Han DH. Aplasia of the internal carotid artery. Acta Neurochir (Wien) 2003;145:117-125. 